\title{
Improved Feed Protein Fractionation Schemes for Formulating Rations with the Cornell Net Carbohydrate and Protein System
}

\author{
C. Lanzas, ${ }^{* 1,2}$ G. A. Broderick, $†$ and D. G. Fox ${ }^{*}$ \\ *Department of Animal Science, Cornell University, Ithaca, NY 14853 \\ †Agricultural Research Service, USDA US Dairy Forage Research Center, 1925 Linden Drive West, Madison, WI 53706
}

\begin{abstract}
Adequate predictions of rumen-degradable protein (RDP) and rumen-undegradable protein (RUP) supplies are necessary to optimize performance while minimizing losses of excess nitrogen $(\mathrm{N})$. The objectives of this study were to evaluate the original Cornell Net Carbohydrate Protein System (CNCPS) protein fractionation scheme and to develop and evaluate alternatives designed to improve its adequacy in predicting RDP and RUP. The CNCPS version 5 fractionates CP into 5 fractions based on solubility in protein precipitant agents, buffers, and detergent solutions: A represents the soluble nonprotein N, B1 is the soluble true protein, $\mathrm{B} 2$ represents protein with intermediate rates of degradation, B3 is the CP insoluble in neutral detergent solution but soluble in acid detergent solution, and $\mathrm{C}$ is the unavailable $\mathrm{N}$. Model predictions were evaluated with studies that measured $\mathrm{N}$ flow data at the omasum. The $\mathrm{N}$ fractionation scheme in version 5 of the CNCPS explained $78 \%$ of the variation in RDP with a root mean square prediction error (RMSPE) of $275 \mathrm{~g} / \mathrm{d}$, and $51 \%$ of the RUP variation with RMSPE of $248 \mathrm{~g} / \mathrm{d}$. Neutral detergent insoluble CP flows were overpredicted with a mean bias of $128 \mathrm{~g} / \mathrm{d}$ ( $40 \%$ of the observed mean). The greatest improvements in the accuracy of RDP and RUP predictions were obtained with the following 2 alternative schemes. Alternative 1 used the inhibitory in vitro system to measure the fractional rate of degradation for the insoluble protein fraction in which $\mathrm{A}=$ nonprotein $\mathrm{N}, \mathrm{B} 1=$ true soluble protein, $\mathrm{B} 2$ $=$ insoluble protein, $\mathrm{C}=$ unavailable protein $\left(\mathrm{RDP}: \mathrm{R}^{2}\right.$ $=0.84$ and RMSPE $=167 \mathrm{~g} / \mathrm{d} ; \mathrm{RUP}: \mathrm{R}^{2}=0.61$ and $\mathrm{RMSPE}=209 \mathrm{~g} / \mathrm{d}$ ), whereas alternative 2 redefined A and $\mathrm{B} 1$ fractions as the non-amino- $\mathrm{N}$ and amino- $\mathrm{N}$ in the soluble fraction respectively $\left(\mathrm{RDP}: \mathrm{R}^{2}=0.79\right.$ with $\mathrm{RMSPE}=195 \mathrm{~g} / \mathrm{d}$ and RUP: $\mathrm{R}^{2}=0.54$ with RMSPE

Received June 9, 2008.

Accepted August 22, 2008.

${ }^{1}$ Corresponding author: cl $272 @$ cornell.edu

${ }^{2}$ Current address: Department of Population Medicine and Diagnostic Sciences, College of Veterinary Medicine, Cornell University, Ithaca, NY 14853.
\end{abstract}

$=225 \mathrm{~g} / \mathrm{d})$. We concluded that implementing alternative 1 or 2 will improve the accuracy of predicting RDP and RUP within the CNCPS framework.

Key words: feed protein fractionation, protein supply, nutritional model

\section{INTRODUCTION}

Excess feeding of $\mathrm{N}$ can contribute to air and water pollution (NRC, 1993). To mitigate negative environmental $\mathrm{N}$ pollution of farming, it is important that diets are formulated to meet, but not exceed, $\mathrm{N}$ requirements of rumen microbes and AA requirements of the ruminant animal (Schwab et al., 2005). Nutritional models help in the process of farm decision making by predicting animal performance and nutrient excretion and assessing diet adequacy under a range of management and feeding situations (Fox et al., 2004). At present, to formulate diets that minimize $\mathrm{N}$ excretion, some aspects of current nutritional models require further improvements, in particular predictions of dietary supply of RDP and RUP, N requirements of rumen microorganisms, and microbial protein supply (Schwab et al., 2005; Lanzas et al., 2007b).

The Cornell Net Carbohydrate and Protein System (CNCPS) accounts for effects of variation in feed protein fractions in predicting feed MP supply, rumen $\mathrm{N}$, and AA balances when developing diets to meet cattle nutrient requirements (Fox et al., 2004). The CNCPS fractionates $\mathrm{CP}$ into 5 fractions based on solubility in protein precipitant agents, buffers, and detergent solutions. This system of protein fractionation was first described 25 yr ago (Van Soest et al., 1981). Some limitations of the system have been identified because of recent research and its implementation by nutritionists. There are several limitations of this fractionation system: 1) the assumption that the $\mathrm{N}$ insoluble in neutral detergent and in acid detergent represents slowly degradable and unavailable protein fractions, respectively, is not valid for all feeds (Waters et al., 1992; Nakamura et al., 1994; Coblentz et al., 1999); 2) the assumption that all of the NPN fraction enters the ammonia pool completely and does not provide amino $\mathrm{N}$ that can stimulate microbial 
Table 1. List of alternative protein fractionation schemes

\begin{tabular}{ll}
\hline Scheme & Modifications ${ }^{1}$ \\
\hline 1 & Original scheme \\
2 & Original scheme with adjusted B3 rates \\
3 & A fraction as NAAN \\
4 & A fraction as NAAN and adjusted B1 rates \\
5 & A fraction as NAAN and adjusted B3 rates \\
6 & A fraction as NAAN and adjusted B1 and B3 rates \\
7 & Aggregated insoluble fraction, A fraction as NPN \\
8 & Aggregated insoluble fraction, A fraction as NAAN \\
9 & Aggregated insoluble fraction, A fraction as NPN, adjusted B1 rates \\
10 & Aggregated insoluble fraction, A fraction as NAAN, adjusted B1 rates \\
\hline${ }^{1}$ NAAN = nonamino N, A fraction computed as indicated in Eq. 6 (A' fraction); NPN: A fraction computed as \\
indicated in Eq. 1 (A fraction); B2 fraction computed as indicated in Eq. 8 (B2' fraction). The fractional rates \\
for the B2 ${ }^{\prime}$ were obtained by the inhibitory in vitro method.
\end{tabular}

growth has caused underprediction of microbial protein production (Aquino et al., 2003); 3) the assumption that fraction $\mathrm{A}$ is completely degraded does not account for the contributions of free amino acids and peptides to the RUP flows (Choi et al., 2002; Volden et al., 2002; Reynal et al., 2007); and 4) despite the RUP flow being very sensitive to degradation rates for the B2 fraction, no method is currently recommended for determining $\mathrm{B} 2$ rates (Lanzas et al., 2007b).

The objectives of this study were to evaluate the original CNCPS protein fractionation system and to develop and evaluate alternatives to improve its ability to accurately predict RDP and RUP using existing literature and currently available methodology. Our approach consisted of developing several modifications that addressed some of the limitations of the original scheme. These modifications were combined to create new fractionation schemes. The original and proposed alternative schemes were evaluated against in vivo RDP supply and RUP flow data and were ranked based on their accuracy.

\section{MATERIALS AND METHODS}

\section{Feed Protein Fractionation Schemes}

Original CNCPS Scheme. The original CNCPS protein fractionation divides feed protein into 5 fractions (Sniffen et al., 1992). The A fraction is the N soluble in buffer and not precipitated by protein precipitating agents such as TCA. It contains peptides, free AA, ammonia, amides, amines, ureides, nucleotides, and nitrates (Reid, 1994). It is determined as

$$
\begin{gathered}
\mathrm{PA}_{\mathrm{j}}=\mathrm{NPN}_{\mathrm{j}} \times\left(\mathrm{SolCP}_{\mathrm{j}} / 1,000\right) \times\left(\mathrm{CP}_{\mathrm{j}} / 1,000\right) \\
(\mathrm{g} / \mathrm{kg} \text { of DM }),
\end{gathered}
$$

where $\mathrm{CP}_{\mathrm{j}}$ is the $\mathrm{CP}$ content of the jth feed, $\mathrm{g} / \mathrm{kg}$ of $\mathrm{DM} ; \mathrm{NPN}_{\mathrm{j}}$ is the nonprotein content of the jth feed, $\mathrm{g} / \mathrm{kg}$ of SolCP; $\mathrm{PA}_{\mathrm{j}}$ is the protein A fraction content of the jth feed, $\mathrm{g} / \mathrm{kg}$ of DM; and $\mathrm{SolCP}_{\mathrm{j}}$ is the buffersoluble $\mathrm{CP}$ content, $\mathrm{g} / \mathrm{kg}$ of $\mathrm{CP}$.

Fraction B1 is measured as the buffer-soluble protein that is not precipitated by protein precipitating agents and is assumed to be very rapidly degraded in the rumen with degradation rates greater than $1.0 / \mathrm{h}$;

$$
\begin{gathered}
\mathrm{PB}_{\mathrm{j}}=\left(\mathrm{SolCP}_{\mathrm{j}} / 1,000\right) \times\left(\mathrm{CP}_{\mathrm{j}} / 1,000\right)-\mathrm{PA}_{\mathrm{j}} \\
(\mathrm{g} / \mathrm{kg} \text { of } \mathrm{DM}),
\end{gathered}
$$

where $\mathrm{CP}_{\mathrm{j}}$ is the $\mathrm{CP}$ content of the $\mathrm{jth}$ feed, $\mathrm{g} / \mathrm{kg}$ of $\mathrm{DM}$; $\mathrm{PA}_{\mathrm{j}}$ is the protein $\mathrm{A}$ fraction content of the jth feed, $\mathrm{g} /$ $\mathrm{kg}$ of $\mathrm{DM} ; \mathrm{PB} 1_{\mathrm{j}}$ is the protein $\mathrm{B} 1$ fraction content of the jth feed, $\mathrm{g} / \mathrm{kg}$ of DM; and $\mathrm{SolCP}_{\mathrm{j}}$ is the buffer-soluble $\mathrm{CP}$ content, $\mathrm{g} / \mathrm{kg}$ of $\mathrm{CP}$.

Fraction $\mathrm{C}$ is the $\mathrm{N}$ insoluble in acid detergent solution that, when multiplied by 6.25 , is assumed to be the protein associated with lignin, tannin-protein complexes, and Maillard products. Ruminal degradation rates and intestinal digestibility for the $\mathrm{C}$ fraction are 0 :

$$
\mathrm{PC}_{\mathrm{j}}=\mathrm{ADICP}_{\mathrm{j}} \times\left(\mathrm{CP}_{\mathrm{j}} / 1,000\right)(\mathrm{g} / \mathrm{kg} \text { of } \mathrm{DM}),
$$

where $\mathrm{ADICP}_{j}$ is the acid detergent insoluble $\mathrm{CP}$ (ADICP) content of the jth feed, $\mathrm{g} / \mathrm{kg} \mathrm{CP} ; \mathrm{CP}_{\mathrm{j}}$ is the $\mathrm{CP}$ content of the jth feed, $\mathrm{g} / \mathrm{kg} \mathrm{DM}$; and $\mathrm{PC}_{\mathrm{j}}$ is the protein $\mathrm{C}$ fraction content of the jth feed, $\mathrm{g} / \mathrm{kg} \mathrm{DM}$.

The B3 fraction is the $\mathrm{CP}$ insoluble in neutral detergent solution, but soluble in acid detergent:

$$
\begin{gathered}
\mathrm{PB}_{\mathrm{j}}=\left(\mathrm{NDICP}_{\mathrm{j}}-\mathrm{ADICP}_{\mathrm{j}}\right) \times\left(\mathrm{CP}_{\mathrm{j}} / 1,000\right) \\
(\mathrm{g} / \mathrm{kg} \text { of } \mathrm{DM}),
\end{gathered}
$$

where $\mathrm{ADICP}_{\mathrm{j}}$ is the $\mathrm{CP}$ insoluble in acid detergent solution content of the jth feed, $\mathrm{g} / \mathrm{kg}$ of $\mathrm{CP} ; \mathrm{CP}_{\mathrm{j}}$ is the $\mathrm{CP}$ content of the jth feed, $\mathrm{g} / \mathrm{kg}$ of DM; NDICP is the insoluble $\mathrm{CP}$ in neutral detergent solution content 
of the jth feed, $\mathrm{g} / \mathrm{kg}$ of $\mathrm{CP}$; and $\mathrm{PB} 3_{\mathrm{j}}$ is the protein B3 fraction content of the jth feed, $\mathrm{g} / \mathrm{kg}$ of DM. It is assumed that the $\mathrm{CP}$ insoluble in neutral detergent solution is protein associated with the cell wall and it is very slowly degraded $(<0.02 / \mathrm{h})$; thus, a high percentage escapes degradation in the rumen.

The B2 fraction represents the intermediate degradable protein with rates of degradation within the range 0.03 to $0.16 / \mathrm{h}$, and it is calculated by difference:

$$
\begin{gathered}
P B 2_{j}=\mathrm{CP}_{j}-\mathrm{PA}_{\mathrm{j}}-\mathrm{PB}_{\mathrm{j}}-\mathrm{PB}_{\mathrm{j}}-\mathrm{PC}_{\mathrm{j}} \\
(\mathrm{g} / \mathrm{kg} \text { of } \mathrm{DM}) .
\end{gathered}
$$

Modifications to the Original CNCPS Scheme. The following modifications were investigated: 1) fractions $\mathrm{A}$ and $\mathrm{B} 1$ were redefined as nonamino $\mathrm{N}$ and buffer-soluble amino $\mathrm{N}$ fractions, respectively; 2) degradation rates for the $\mathrm{B} 1$ were adjusted as shown below; 3) the original insoluble B2 and B3 were combined into one fraction; and 4) degradation rates of B3 were adjusted as shown below.

First, the A and B1 fractions were redefined as nonAA N (NAAN; PA') and AA N (AAN; PB1') in the buffer-soluble fraction:

$$
\begin{aligned}
\mathrm{PA}_{\mathrm{j}}^{\prime} & =\left(1,000-\mathrm{AAN}_{\mathrm{j}}\right) \times\left(\mathrm{SolCP}_{\mathrm{j}} / 1,000\right) \\
& \times\left(\mathrm{CP}_{\mathrm{j}} / 1,000\right)(\mathrm{g} / \mathrm{kg} \text { of } \mathrm{DM})
\end{aligned}
$$

and $\mathrm{PB}^{\prime}{ }_{\mathrm{j}}=\left(\mathrm{SolCP}_{\mathrm{j}} / 1,000\right) \times\left(\mathrm{CP}_{\mathrm{j}} / 1,000\right)-\mathrm{PA}^{\prime} \mathrm{j}$

$$
(\mathrm{g} / \mathrm{kg} \text { of } \mathrm{DM}) \text {, }
$$

where $\mathrm{CP}_{\mathrm{j}}$ is the $\mathrm{CP}$ content of the $\mathrm{jth}$ feed, $\mathrm{g} / \mathrm{kg} \mathrm{DM}$; $\mathrm{AAN}_{\mathrm{j}}$ is the AA $\mathrm{N}$ content of the jth feed, $\mathrm{g} / \mathrm{kg}$ of SolCP; $\mathrm{PA}_{j}^{\prime}$ is the protein A fraction content of the jth feed, $\mathrm{g} / \mathrm{kg}$ of $\mathrm{DM}$; $\mathrm{PB}_{1}^{\prime}{ }_{\mathrm{j}}$ is the protein $\mathrm{B} 1$ fraction content of the jth feed, $\mathrm{g} / \mathrm{kg}$ of DM; and $\mathrm{SolCP}_{\mathrm{j}}$ is the buffer-soluble $\mathrm{CP}$ content, $\mathrm{g} / \mathrm{kg}$ of $\mathrm{CP}$. In addition, the $\mathrm{B} 1$ ' fraction was assumed to pass at the same rate as liquids leaving the rumen.

Second, degradation rates of the B1 fraction in the CNCPS feed library exceed most of the published values for in vitro soluble proteins (Mahadevan et al., 1980; Broderick et al., 1989; Peltekova and Broderick, 1996; Hedqvist and Udén, 2006). The effects of adjusting the $\mathrm{B} 1$ rates to reflect observed in vitro rates were investigated (Table 1). The adjustment of $\mathrm{B} 1$ rates was assumed independent of the definition of $\mathrm{A}$ and B1 fractions because the ranges of reported fractional degradation rates of soluble protein and peptides degradation are similar (Volden et al., 2002).
Third, recent studies in which the kinetics of NDICP disappearance has been determined indicated that digestion rates of NDICP are considerably greater than the rates found in the CNCPS feed library for the B3 fraction (Rossi et al., 1997; Juarez, 1998; Coblentz et al., 1999; McBeth et al., 2003). The rates for the B3 fraction were increased.

Fourth, the aggregation of the original B2 and B3 fractions into one fraction (PB2') was performed because previous sensitivity analyses indicated that unless the rates for fractions within the true insoluble protein (B2 and B3) differed by several magnitudes $(>\times 10)$, the model predictions were insensitive to the presence of different fractions (Lanzas et al., 2007b). The new fraction was renamed PB2':

$$
\mathrm{PB} 2_{\mathrm{j}}{ }^{\prime}=\mathrm{CP}_{\mathrm{j}}-\mathrm{PA}_{\mathrm{j}}-\mathrm{PB}_{\mathrm{j}}-\mathrm{PC}_{\mathrm{j}}(\mathrm{g} / \mathrm{kg} \text { of } \mathrm{DM}) .[8]
$$

Degradation rates based on the inhibitory in vitro (IIV) method were used for the PB2' fraction (Broderick, 1987; Broderick and Clayton, 1992; Broderick et al., 2004a,b).

Alternatives schemes were developed by incorporating various combinations of the modifications described above into the CNCPS protein fractionation scheme. Both the original and alternative schemes tested in this study are listed in Table 1.

\section{Evaluation of the Feed Protein Fractionation Schemes}

The ability of the original and alternative schemes to predict RDP supply and RUP flows determined using omasal sampling technique was assessed. There are some advantages of using omasal data for estimating $\mathrm{N}$ fractions (Ahvenjarvi et al., 2000): 1) there is substantially less endogenous $\mathrm{N}$ secreted into the rumen than into the duodenum, and 2) rumen microbes are measured before they reach the abomasum where they are digested, allowing the digesta $\mathrm{N}$ to be separated into particle- and liquid-associated bacteria, protozoa, and soluble and insoluble dietary $\mathrm{N}$ fractions.

Database Description. Five studies designed to test the effect of dietary protein content and supplementation on $\mathrm{N}$ metabolism and animal performance in lactating dairy cows in which omasal flows were determined were used to evaluate the ability of the protein fractionation schemes to predict RDP supply and RUP flows (Reynal and Broderick, 2003, 2005; Reynal et al., 2003, 2005; Olmos Colmenero and Broderick, 2006a,b; Brito and Broderick, 2006, 2007; Brito et al., 2006, 2007; Table 2). 
Table 2. Descriptive statistics for the studies used to evaluate the ability of the protein fractionation schemes to predict RDP supply and flow of RUP

\begin{tabular}{|c|c|c|c|c|c|}
\hline Item & \multicolumn{5}{|c|}{ Descriptive statistics } \\
\hline \multicolumn{6}{|l|}{ Diet composition and intake } \\
\hline NDF, g/kg DM & 22 & 250 & 2.4 & 22.4 & 30 \\
\hline $\mathrm{N}, \mathrm{g} / \mathrm{kg} \mathrm{DM}$ & 22 & 27.8 & 2.63 & 21.6 & 32.5 \\
\hline $\mathrm{NE}_{\mathrm{L}}, \mathrm{MJ} / \mathrm{kg} \mathrm{DM}$ & 22 & 6.28 & 0.251 & 5.94 & 6.90 \\
\hline DIM, d & 22 & 91 & 19 & 72 & 120 \\
\hline Milk, kg/d & 22 & 39 & 2.9 & 32.9 & 42.8 \\
\hline Fat yield, $\mathrm{kg} / \mathrm{d}$ & 22 & 1.3 & 0.12 & 1 & 1.6 \\
\hline True protein yield, $\mathrm{kg} / \mathrm{d}$ & 22 & 1.2 & 0.11 & 0.9 & 1.3 \\
\hline Urine $\mathrm{N}, \mathrm{g} / \mathrm{d}$ & 17 & 154 & 48.7 & 63 & 240 \\
\hline Fecal N, g/d & 17 & 211 & 28.7 & 154 & 275 \\
\hline \multicolumn{6}{|l|}{ Omasal $\mathrm{N}$ flows } \\
\hline NDIN, $g / d$ & 17 & 25 & 7.7 & 14 & 45 \\
\hline ADIN, $\mathrm{g} / \mathrm{d}$ & 18 & 20 & 23.6 & 3 & 66 \\
\hline
\end{tabular}

Simulations and Evaluation. Simulations were made using a spreadsheet version of the rumen submodel of the CNCPS as described by Fox et al. (2004) with new passage rate equations developed by Seo et al. (2006) and a revised feed carbohydrate fractionation scheme (Lanzas et al., 2007a). The following predicted outputs were evaluated against the in vivo data:

1. RUP flows (g/d):

$$
\begin{gathered}
\text { Observed RUP flows }=(\text { NAN }- \text { Microbial NAN }) \\
\times 6.25
\end{gathered}
$$

Predicted RUP flows $=\sum_{j=1}^{j} R E P B 1_{j}+R E P B 2_{j}+R E P B 3_{j}+R E P C_{j}$;

2. RDP supply (CP intake - RUP flows) (g/d):

Observed RDP supply $=$ Total CP intake

$$
\text { - RUP flow; }
$$

Predicted RDP flows $=\sum_{j=1}^{j} R D P A_{J}+R D P B 1_{J}+R D P B 2_{j}+R D P B 3_{j}$;

\section{NDICP flows $(\mathrm{g} / \mathrm{d})$ :}

Observed NDICP flow $=$ NDIN flow $\times 6.25 ; \quad[13]$

Predicted NDICP flow $=\sum_{j=1}^{j} R E P B 3_{j}+R E P C_{j} ;[14]$

where NDIN is the neutral detergent insoluble nitrogen, $\mathrm{RDPA}_{\mathrm{j}}$ is ruminally degraded protein A fraction of the jth feedstuff, $\mathrm{RDPB}_{\mathrm{ij}}$ is the ruminally degraded protein $B_{i}$ fraction of the $j$ th feedstuff, $R E P B_{i j}$ is the ruminally escaped protein $B_{i}$ fraction of the jth feedstuff, and $\mathrm{REPC}_{\mathrm{j}}$ is the ruminally escaped protein $\mathrm{C}$ fraction of the jth feedstuff.

The following statistical tests were used to assess the adequacy of the model predictions (Tedeschi, 2006). Accuracy was determined using the concordance correlation coefficient $(\mathbf{C C C})$ and accuracy index $(\mathbf{C b}$; Lin, 1989). The concordance correlation coefficient evaluates the agreement between observed and predicted by measuring the variation from the $45^{\circ}$ line through the origin (Lin, 1989). Mean square error (MSE), mean square prediction error (MSPE) and its partition into 3 independent and additive components (Theil, 1961; mean bias, slope bias, and random unexplained errors), and linear regression were also performed.

\section{RESULTS}

Tables 3 and 4 present the fractions and degradation rates for the feeds used in the evaluation. Table 3 has the average values for the protein fractions in the feeds 
Table 3. Feed protein fractions in the feeds included in the evaluation

\begin{tabular}{|c|c|c|c|c|c|c|c|c|}
\hline Feed & \multicolumn{8}{|c|}{ Protein fractions $^{1}$} \\
\hline Alfalfa silage & 224.8 & 496.2 & 829.5 & 170.5 & 136.4 & 863.6 & 92.2 & 28.9 \\
\hline Blood meal & $1,000.0$ & 50.0 & 60.0 & 940.0 & 10.0 & 990.0 & 64.0 & 12.0 \\
\hline Canola meal & 427.0 & 323.2 & 652.2 & 347.8 & 170.0 & 830.0 & 71.7 & 40.3 \\
\hline Corn gluten meal & 651.9 & 41.4 & 740.7 & 259.3 & 10.0 & 990.0 & 81.0 & 64.0 \\
\hline Expeller soybean & & & & & & & & \\
\hline $\begin{array}{l}\text { meal (SBM) } \\
\text { Lignosulfonate SBM }\end{array}$ & $\begin{array}{l}489.4 \\
496.6\end{array}$ & $\begin{array}{l}61.3 \\
48.3\end{array}$ & $\begin{array}{l}533.3 \\
500.0\end{array}$ & $\begin{array}{l}466.7 \\
500.0\end{array}$ & $\begin{array}{l}10.0 \\
20.0\end{array}$ & $\begin{array}{l}990.0 \\
980.0\end{array}$ & $\begin{array}{l}107.0 \\
323.6\end{array}$ & $\begin{array}{l}23.0 \\
74.6\end{array}$ \\
\hline $\begin{array}{l}\text { Lignosulfonate SBM } \\
\text { Roasted soybeans }\end{array}$ & $\begin{array}{l}490.0 \\
400.0\end{array}$ & 57.5 & $1,000.0$ & 0.0 & $\begin{array}{l}20.0 \\
20.0\end{array}$ & $\begin{array}{l}900.0 \\
980.0\end{array}$ & $\begin{array}{r}02.0 \\
82.5\end{array}$ & $\begin{array}{l}14.0 \\
34.4\end{array}$ \\
\hline Rolled HMSC ${ }^{2}$ & 86.4 & 321.9 & 935.4 & 64.6 & 103.5 & 896.5 & 34.7 & 6.1 \\
\hline Solvent SBM & 530.8 & 199.7 & 537.8 & 462.2 & 20.0 & 980.0 & 15.2 & 5.2 \\
\hline
\end{tabular}

${ }^{1} \mathrm{NAAN}=$ non-AA N; NDICP $=$ neutral detergent insoluble CP; ADICP = acid detergent insoluble CP. The NPN fraction was assayed with TCA; NPN is the A fraction of the original scheme (Eq. 1); true protein is the B1 fraction of the original scheme (Eq. 2); NPN values were corrected by subtracting total amino nitrogen from total nitrogen; NAAN is the modified A fraction (Eq. 6) (= A' fraction); AAN is the modified B1 fraction (Eq. 7) ( = B1' fraction).

${ }^{2} \mathrm{HMSC}=$ high-moisture shelled corn.

included in the evaluation. For the protein concentrates, the A fraction of the original scheme represented approximately $500 \mathrm{~g} / \mathrm{kg}$ of the soluble CP. When the soluble protein was corrected for its amino $\mathrm{N}$ content, the average amino $\mathrm{N}$ content was greater than $800 \mathrm{~g} /$ $\mathrm{kg}$ of soluble CP. Table 4 lists the current feed library rates, the adjusted rates for the $\mathrm{B} 1$ and $\mathrm{B} 3$ fractions, and the rates for the $\mathrm{B}^{\prime}$ fractions.

The original scheme overpredicted the RDP supply with a mean bias of $149 \mathrm{~g} / \mathrm{d}$ ( $5 \%$ of the predicted and observed mean; Table 5 and Figure 1). The regressed residuals (observed - predicted) against predicted $\mathrm{RDP}$ had significant intercept and slope $[\mathrm{Y}=-148.7-0.28$ (X
- 3,050.8)], indicating the presence of significant slope and mean bias. The original scheme explained more variation in the RDP supply $\left(R^{2}=0.78\right)$ than for the RUP flows $\left(\mathrm{R}^{2}=0.51\right.$; Table 5$)$. The original scheme underpredicted RUP flow with a mean bias of $152 \mathrm{~g} / \mathrm{d}$ ( $12 \%$ of the predicted mean and $14 \%$ of the observed mean). Similar to RDP, the regressed residuals against predicted RUP flow had significant intercept and slope $[\mathrm{Y}=151.8-0.39(\mathrm{X}-1,086.7)]$. Four studies that also measured omasal NDICP flows were used to evaluate the predictions of the flow of NDICP out of the rumen (Reynal and Broderick, 2005; Brito et al., 2006, 2007; Olmos Colmenero and Broderick, 2006b). The original

Table 4. Degradation rates $(/ \mathrm{h})$ for the protein fractions of the feeds used in the evaluation.

\begin{tabular}{|c|c|c|c|c|c|}
\hline Feed & \multicolumn{5}{|c|}{ Cornell Net Carbohydrate and Protein System } \\
\hline Alfalfa silage & 1.5 & 0.28 & 0.0180 & 0.14 & 0.04 \\
\hline Canola meal & 2.3 & 0.46 & 0.0002 & 0.05 & 0.12 \\
\hline Corn gluten meal & 1.5 & 0.2 & 0.0050 & 0.02 & 0.02 \\
\hline Corn silage & 1.5 & 0.28 & 0.0180 & 0.03 & 0.04 \\
\hline Lignosulfonate SBM & 2.3 & 0.46 & 0.0020 & 0.04 & 0.04 \\
\hline Roasted soybeans & 2.3 & 0.46 & 0.0020 & 0.04 & 0.05 \\
\hline Rolled HMSC & 1.5 & 0.5 & 0.0200 & 0.02 & 0.02 \\
\hline Solvent SBM & 2.3 & 0.46 & 0.0100 & 0.06 & 0.17 \\
\hline
\end{tabular}

${ }^{1}$ AdjB1 rates are the adjusted rates for the fraction B1 and were based on several published sources (Broderick et al., 1989; Peltekova and Broderick, 1996; Hedqvist and Udén, 2006).

${ }^{2}$ AdjB3 rates are the adjusted rates for the fraction B3 and were based on several published sources (Rossi et al., 1997; Juarez, 1998; Coblentz et al., 1999; McBeth et al., 2003; Pichard et al., 2005; Ogden et al., 2006).

${ }^{3} \mathrm{IIV}=$ inhibitory in vitro. Corn silage, rolled high-moisture shelled corn (HMSC) and canola meal rates were assigned based on relative ranking compared with the other feeds. 
scheme overpredicted the omasal flow of NDICP (Table 6 ), with a mean bias of $62.3 \mathrm{~g} / \mathrm{d}$, which represented $28.5 \%$ of the predicted mean and $40 \%$ of the observed mean. For the study with the greatest proportion of protein as B3 and C fraction (Reynal and Broderick, 2005), the averaged mean bias for the study was as great as $204 \mathrm{~g} / \mathrm{d}$, representing $40 \%$ of the predicted mean and $97 \%$ of the observed mean. Adjusting the B3 rates to reflect available data (scheme 2; Table 1) resulted in a decrease in the RMSPE and lower mean bias $(21 \mathrm{~g} / \mathrm{d}$; Table 6$)$. However, the NDICP flows were still overpredicted when the adjusted rates were used. Overall, the predicted contribution of the NDICP to the RUP flows was greater than observed because the NDICP fraction was more extensively degraded in the rumen (Table 2).

Statistical measures for the evaluation of the alternative protein fractionation schemes listed in Table 1 are summarized in Table 5. Table 7 ranks the schemes by their accuracy in predicting RDP and RUP. The original scheme ranked seventh and fifth in predicting RDP and RUP, respectively, whereas scheme 7 (in which the insoluble fraction was combined into 1 fraction, and fraction $\mathrm{A}=\mathrm{NPN}$ ) was the best. The CCC ranked the schemes similarly. As a general trend, adjusting for the AAN in the soluble protein $\left(\mathrm{A}^{\prime}\right.$ and $\mathrm{B}^{\prime}$ fractions, Eq. 6 ; schemes 3 and 5) decreased RDP compared with the original scheme. Aggregating B2 and B3 pools (B2' fraction, Eq. 8; schemes 7 to 10) resulted in an increase in the RUP flows. Schemes 3 ( $\mathrm{A}^{\prime}$ and $\mathrm{B} 1^{\prime}$ fractions), 7 (aggregated insoluble B2' fraction), and 9 (aggregated insoluble B2' fraction, A fraction as NPN, and adjusted $\mathrm{B} 1$ rates) were the schemes that resulted in an overall improvement in the accuracy of both RDP supply and RUP flow predictions. The scheme that performed the worst was scheme 10, in which $\mathrm{A}$ fraction and $\mathrm{B} 1$ rates were adjusted and the insoluble fraction was aggregated. Scheme 10 overpredicted the amount of escaping soluble and insoluble protein fractions.

\section{DISCUSSION}

The original scheme overpredicted the RDP supply and underpredicted RUP flows when compared with omasal flow data. Evaluations using previous versions of the CNCPS model reported the same directionality for biases (Kohn et al., 1998; Bateman et al., 2001b), but the RMSPE in this study are considerably lower than previously reported (Kohn et al., 1998; Bateman et al., 2001a). The greater accuracy observed in this study is probably because of a more homogeneous database and the use of actual feed analyses rather than feed library values. Likely, contributing factors to the overprediction of RDP supply in the original scheme are the predicted high degradability of the $\mathrm{B} 2$ fraction and the almost complete degradation of the soluble protein $(\mathrm{B} 1+\mathrm{A})$. For most feeds, the B2 fraction represents the largest protein pool size (Sniffen et al., 1992) and the feed library degradation rates for the $\mathrm{B} 2$ fraction are greater than most of the in situ and in vitro estimates (NRC, 2001). In addition, for most feeds, the B1 fraction represents a small percentage of the total soluble protein (Table 3), and most of the soluble protein is allocated into the A fraction, which is assumed to be immediately converted to ammonia. As a result, and similar to results with the in situ method, almost no soluble protein is predicted to be in the RUP. On average, the predicted RUP contained mostly B2 protein $(\sim 75 \%)$, B3 $+\mathrm{C}$ fractions $(\sim 20 \%)$, and small amounts of B1 ( $5 \%)$. However, for the studies included in the evaluation, the free AA-N was escaping in a proportion similar to NDICP flows (Table 2). In other studies, the peptide- $\mathrm{N}$ was identified to be the most important amino $\mathrm{N}$ flowing out from the rumen in the liquid phase (Choi et al., 2002). Within the insoluble fraction, contributions of the B3 and C fractions were also overestimated. The original scheme overpredicted the NDICP flow out of the rumen (Table 6). The CNCPS feed library values for the degradation rates of the B3 fraction are virtually zero; therefore, it is predicted to almost completely escape microbial degradation in the ruminal. When values for the degradation rates for the B3 fraction were reassessed and adjusted (Table 4), the predictions of NDICP were improved (Table 6). However, adjusting rates for the B3 fraction (which are greater than the default feed library rates) with no other changes in the fractionation (scheme 2; Table 1) increased the bias in predicting RDP and RUP. The CNCPS model was only sensitive to NDICP measurements for feeds that contain high proportions of protein as NDICP (Lanzas et al., 2007b), but it is for those feeds (i.e., tropical forages) that rates have been reported (Juarez, 1998; Coblentz et al., 1999; Ogden et al., 2006) to be consistently greater than CNCPS B3 feed library values. Reported values for NDICP degradation rates might be similar or slightly greater than NDF degradation rates (Pichard, 1977). This fact has lead to the question of the appropriateness of using the $\mathrm{N}$ isolated in detergent solution as an indicator of the slowly protein degradation fraction.

Changes in the fractionation scheme were proposed to address some of the issues indicated previously. The contribution of the soluble $\mathrm{N}$ fractions to the RUP flows was improved by accounting for all the AAN pool in the soluble protein and adjusting B1 rates. Adjusting the B1 fraction to represent all of the AAN pool (scheme 3; Table 1) resulted in the lowest bias in RDP and RUP of all the schemes. From a nutritional point of view, the AAN fraction represents a more homogeneous 
Table 6. Evaluation of the Cornell Net Carbohydrate and Protein System (CNCPS) predictions of the escape of the neutral detergent $\mathrm{CP}$ using the original protein fractionation scheme with either the default feed library B3 rates or adjusted B3 rates based on published data $(\mathrm{n}=17)$

\begin{tabular}{lcc}
\hline Item $^{1}$ & Default B3 rates & Adjusted B3 rates \\
\hline Intercept & $96.4(P<0.0001)$ & $101(P<0.0001)$ \\
Slope & $0.27(P<0.0001)$ & $0.31(P<0.0001)$ \\
$\mathrm{R}^{2}$ & 0.77 & 0.78 \\
RMSE & 24.0 & 24.0 \\
Mean bias (MB) & -62.31 & -21 \\
MB as \% of predicted mean & 28.5 & 11.8 \\
MB as \% of observed mean & 39.8 & 13.4 \\
MSPE & $16,281.8$ & $9,604.0$ \\
Partition of MSPE & 23.8 & 4.5 \\
Mean bias $\left(\mathrm{U}^{\mathrm{M}}\right), \%$ & 73 & 90.3 \\
Slope not equal to 1 $\left(\mathrm{U}^{\mathrm{R}}\right), \%$ & 3.2 & 5.2 \\
Lack of correlation $\left(\mathrm{U}^{\mathrm{D}}\right), \%$ & 127.6 & 98 \\
RMSPE & 0.43 & 0.54 \\
CCC & 0.50 & 0.61 \\
Cb & &
\end{tabular}

${ }^{1} \mathrm{RMSE}=$ root mean square error; MSPE $=$ mean square prediction error; RMSPE $=$ root mean square prediction error; $\mathrm{Cb}=$ bias correction factor; $\mathrm{CCC}=$ concordance correlation coefficient. Mean bias $=$ observed - predicted.

fraction than the NPN fraction. The NPN fraction (fraction A of the original scheme) contains both AAN (i.e., peptides and free AA) and NAAN (i.e., ammonia, amides, amines, ureides, nucleotides and nitrates). However, AAN and NAAN represent 2 distinct nutri-
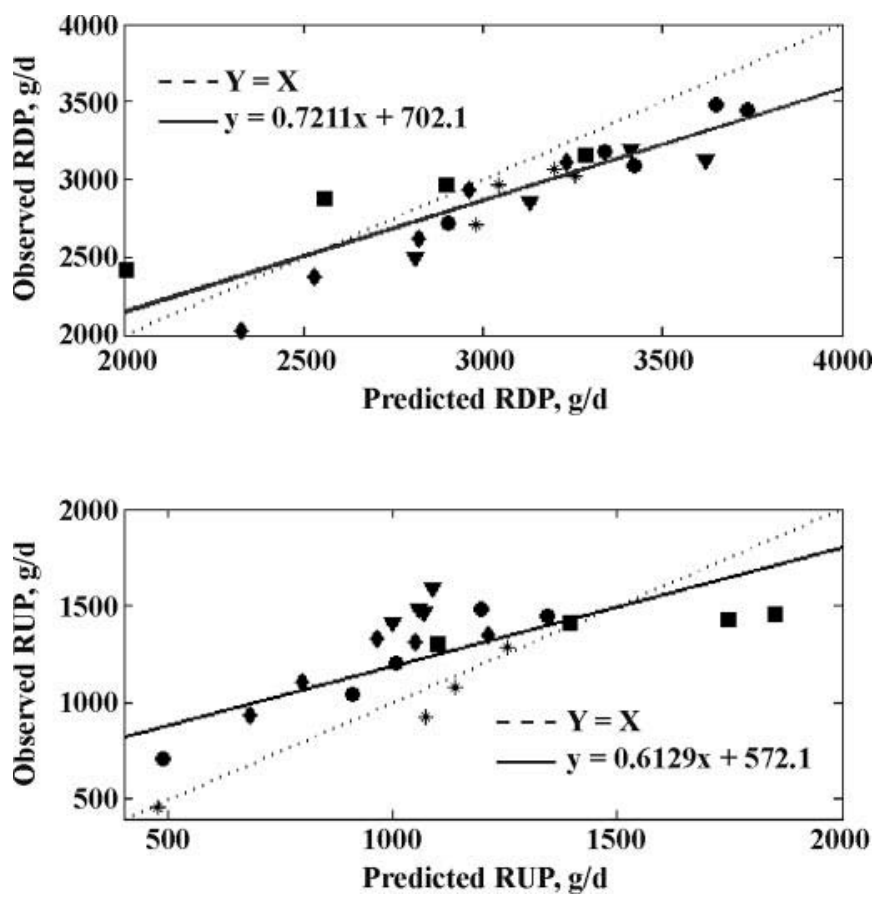

Figure 1. Predictions of the RDP supply and RUP flow using the original Cornell Net Carbohydrate and Protein System scheme for the following studies: Reynal et al. (2003) ( ), Reynal and Broderick (2005) (ם), Olmos Colmenero and Broderick (2006b) ( ), Brito and Broderick (2007) $\left(^{*}\right)$, and Brito et al. (2006) ( $\left.\mathbf{\Lambda}\right)$. tional fractions. Peptides and free AA may stimulate microbial growth more than ammonia (Van Kessel and Russell, 1996). In addition, although the original A fraction is assumed to be completely degraded in the rumen, recent studies showed that peptides and free AA contributed to the RUP flows (Choi et al., 2002; Volden et al., 2002; Reynal et al., 2007). For corn- and alfalfa-silage based diets, the amount of $\mathrm{N}$ flowing as free AA out of the rumen exceeds the outflow of $\mathrm{N}$ insoluble in neutral detergent (Olmos Colmenero and Broderick, 2006b). Therefore, the distinction between the fraction containing NAAN and AAN is important in predicting both RUP and microbial protein flows. In addition, having the $\mathrm{B} 1$ fraction include all AAN may be less variable than the current B1 fraction for most feeds, and therefore, it may be more robust for use as default feed library values. Silages are the feeds with the greatest variation in the composition of the soluble protein fraction (McDonald et al., 1991). But in well-fermented silages, with predominantly lactic acid fermentation, free AAN is still the main fraction within the NPN because lactic acid bacteria have limited ability to ferment AA, with the exception of serine and arginine (Givens and Rulquin, 2004).

Aggregating the insoluble fractions and using the IIV rates for the combined fraction (scheme 7 ; Table 1) resulted in the scheme with the greatest accuracy for both RDP and RUP (Table 7). It also resulted in a change in the sign of the bias (overpredicting RUP and underpredicting RDP), but did not address the underrepresentation of the soluble $\mathrm{N}$ fractions in the RUP flows. Predicted RDP, RUP, and AA flows were very sensitive to protein B2 degradation rates (Lanzas et al., 
Table 7. Ranking of the protein fractionation schemes based on their ability to predict RDP supply and RUP flow as assessed by their root mean square prediction error (RMSPE)

\begin{tabular}{lccccc}
\hline & \multicolumn{2}{c}{ RDP } & & \multicolumn{2}{c}{ RUP } \\
\cline { 2 - 3 } \cline { 5 - 6 } Scheme $^{1}$ & RMSPE & Ranking & & RMSPE & Ranking \\
\hline 1 & 248.3 & 7 & & 275 & 5 \\
2 & 284.2 & 9 & & 292.2 & 8 \\
3 & 185.2 & 3 & & 225.5 & 2 \\
4 & 210.1 & 5 & & 317.3 & 9 \\
5 & 256 & 8 & & 241.9 & 4 \\
6 & 203 & 4 & & 283.7 & 6 \\
7 & 166.6 & 1 & & 209.5 & 1 \\
8 & 243.6 & 6 & & 284.1 & 7 \\
9 & 183.3 & 2 & & 239.1 & 3 \\
10 & 445.3 & 10 & & 466.8 & 10 \\
\hline
\end{tabular}

${ }^{1}$ Scheme descriptions: $1=$ original; $2=$ original with adjusted $\mathrm{B} 3$ rates; $3=\mathrm{A}$ fraction as non-AA N (NAAN; A' fraction); $4=\mathrm{A}$ fraction as NAAN and adjusted B1 rates; $5=\mathrm{A}$ fraction as NAAN and adjusted $\mathrm{B} 3$ rates; $6=\mathrm{A}$ fraction as NAAN and adjusted $\mathrm{B} 1$ and $\mathrm{B} 3$ rates; 7 = aggregated insoluble fraction [inhibitory in vitro (IIV) rates], $\mathrm{A}$ as NPN; $8=$ aggregated insoluble fraction (IIV rates), A as NAAN; 9 = aggregated insoluble fraction (IIV rates), A fraction as NPN, and adjusted $\mathrm{B} 1$ rates; and $10=$ aggregated insoluble fraction (IIV rates), A fraction as NAAN, and adjusted B1 rates.

2007b). Combining both insoluble fractions (B2 + B3) makes the currently infeasible task of measuring degradation rates of these 2 fractions much easier. An implicit assumption in using the IIV rates for the insoluble fraction is that the rate for the insoluble fraction is directly proportional to the overall rate. The incubation time for the IIV method is short; therefore, the overall fractional rate may be bias toward the fastest degradable protein. For most feeds, the true soluble protein B1 represents a small percentage of the total protein. An approach not tested but that would likely increase the contribution of the soluble protein and reduce the overprediction of the RUP flow is defining the A fraction as NAAN, and the using of the Michaelis-Menten variant of the IIV method (Broderick and Clayton, 1992) to obtain rates for the combined insoluble fraction.

\section{Proposed Modifications}

To implement the best-ranked scheme (scheme 7 = aggregated insoluble fraction, A as NPN), the following aspects should be considered: 1) to implement the scheme within the current feed library, the new insoluble rate should be applied to both the B2 and B3 fractions, which would in practice collapse the 2 fractions into 1 fraction in the current versions of CNCPS versions 5 and $6 ; 2$ ) the IIV method can be simplified by determining total $\mathrm{N}$ of the TCA-supernatants with either the combustion assay or Kjeldahl (Broderick et al., 2004b); and 3) for some groups of feeds the method may be less accurate, and modifications or alternative methods should be considered for these feeds. Degradation rates for feeds containing high levels of ammonia and free AA (e.g., grass and legume silages) are less accurate (Broderick, 1994). For those feeds, to reduce the background levels of the ammonia and free AA background levels, only the residue insoluble in borate phosphate buffer could be used for the IIV method. The method may also not be accurate for tannin-containing forages; for those forages, the Michaelis-Menten variant of the IIV method may be a more feasible approach (Broderick, 1994).

In conclusion, although further testing of more diverse dairy rations will be necessary, improvements in the accuracy of RDP and RUP predictions by the CNCPS protein fractionation scheme can be obtained when the insoluble fractions B2 and B3 are combined, resulting in a single pool and degradation rate, which can be determined by the IIV method. Evaluations of the NDICP flows indicated the ruminal escape of the NDICP was overpredicted, and thus the concept that the $\mathrm{N}$ insoluble in neutral detergent represents the slow degradable protein might not be appropriate and needs revision. Improvements in the accuracy of the predictions were also achieved when AAN was accounted for in the soluble fraction.

\section{ACKNOWLEDGMENTS}

We would like to thank Luis O. Tedeschi (Texas A\&M University, College Station) for helpful suggestions on previous versions of the manuscript.

\section{REFERENCES}

Ahvenjarvi, S., A. Vanhatalo, P. Huhtanen, and T. Varvikko. 2000. Determination of reticulo-rumen and whole-stomach digestion in lactating cows by omasal canal or duodenal sampling. Br. J. Nutr. 83:67-77.

Aquino, D. L., L. O. Tedeschi, C. Lanzas, S. S. Lee, and J. B. Russell. 2003. Evaluation of CNCPS predictions of milk production of dairy cows fed alfalfa silage. in Cornell Nut. Conf. Feed Manuf. Cornell University, Syracuse, NY.

Bateman, H. G., J. H. Clark, R. A. Patton, C. J. Peel, and C. G. Schwab. 2001a. Prediction of crude protein and amino acid passage to the duodenum of lactating cows by models compared with in vivo data. J. Dairy Sci. 84:665-679.

Bateman, H. G. II, J. H. Clark, R. A. Patton, C. J. Peel, and C. G. Schwab. 2001b. Accuracy and precision of computer models to predict passage of crude protein and amino acids to the duodenum of lactating cows. J. Dairy Sci. 84:649-664.

Brito, A. F., and G. A. Broderick. 2006. Effect of varying dietary ratios of alfalfa silage to corn silage on production and nitrogen utilization in lactating dairy cows. J. Dairy Sci. 89:3924-3938.

Brito, A. F., and G. A. Broderick. 2007. Effects of different protein supplements on milk production and nutrient utilization in lactating dairy cows. J. Dairy Sci. 90:1816-1827.

Brito, A. F., G. A. Broderick, and S. M. Reynal. 2006. Effect of varying dietary ratios of alfalfa silage to corn silage on omasal flow and microbial protein synthesis in dairy cows. J. Dairy Sci. 89:3939-3953. 
Brito, A. F., G. A. Broderick, and S. M. Reynal. 2007. Effects of different protein supplements on omasal nutrient flow and microbial protein synthesis in lactating dairy cows. J. Dairy Sci. 90:1828-1841.

Broderick, G. A. 1987. Determination of protein-degradation rates using a rumen in vitro system containing inhibitors of microbial nitrogen metabolism. Br. J. Nutr. 58:463-475.

Broderick, G. A. 1994. Quantifying forage protein quality. Pages 200228 in Forage quality, evaluation, and utilization. G. Fahey, M. Collins, D. Mertens, and L. E. Moser, ed. ASA, CSSA, and SSSA, Madison, WI.

Broderick, G. A., and M. K. Clayton. 1992. Rumen protein-degradation rates estimated by nonlinear regression analysis of MichaelisMenten in vitro data. Br. J. Nutr. 67:27-42.

Broderick, G. A., M. L. Murphy, and P. Uden. 2004a. Effect of inhibitor concentration and end-product accumulation on estimates of ruminal in vitro protein degradation. J. Dairy Sci. 87:13601371

Broderick, G. A., P. Uden, M. L. Murphy, and A. Lapins. 2004b. Sources of variation in rates of in vitro ruminal protein degradation. J. Dairy Sci. 87:1345-1359.

Broderick, G. A., R. J. Wallace, and E. R. Orskov. 1989. Control of rate and extent of protein degradation. Pages 541-592 in Physiological Aspects of Digestion and Metabolism in Ruminants. T. Tsuda, Y. Sasaki, and R. Kawashima, ed. Academic Press Inc., San Diego, CA

Choi, C. W., S. Ahvenjarvi, A. Vanhatalo, V. Toivonen, and P. Huhtanen. 2002. Quantitation of the flow of soluble non-ammonia nitrogen entering the omasal canal of dairy cows fed grass silage based diets. Anim. Feed Sci. Technol. 96:203-220.

Coblentz, W. K., J. O. Fritz, W. H. Fick, R. C. Cochran, J. E. Shirley, and J. E. Turner. 1999. In situ disappearance of neutral detergent insoluble nitrogen from alfalfa and eastern gamagrass at three maturities. J. Anim. Sci. 77:2803-2809.

Fox, D. G., L. O. Tedeschi, T. P. Tylutki, J. B. Russell, M. E. Van Amburgh, L. E. Chase, A. N. Pell, and T. R. Overton. 2004. The Cornell Net Carbohydrate and Protein System model for evaluating herd nutrition and nutrient excretion. Anim. Feed Sci. Technol. 112:29-78.

Givens, D. I., and H. Rulquin. 2004. Utilisation by ruminants of nitrogen compounds in silage-based diets. Anim. Feed Sci. Technol. 114:1-18.

Hedqvist, H., and P. Udén. 2006. Measurement of soluble protein degradation in the rumen. Anim. Feed Sci. Technol. 126:1-21.

Juarez, F. 1998. Evaluation of the nutritive value of four tropical grasses receiving two levels of nitrogen fertilization. Pages 1-125 in Animal Science. Cornell University, Ithaca, NY.

Kohn, R. A., K. F. Kalscheur, and M. Hanigan. 1998. Evaluation of models for balancing the protein requirements of dairy cows. J. Dairy Sci. 81:3402-3414.

Lanzas, C., C. J. Sniffen, S. Seo, L. O. Tedeschi, and D. G. Fox. 2007a. A revised CNCPS feed carbohydrate fractionation scheme for formulating rations for ruminants. Anim. Feed Sci. Technol. 136:167-190.

Lanzas, C., L. O. Tedeschi, S. Seo, and D. G. Fox. 2007b. Evaluation of protein fractionation systems used in formulating rations for dairy cattle. J. Dairy Sci. 90:507-521.

Lin, L. I.-K. 1989. A concordance correlation coefficient to evaluate reproducibility. Biometrics 45:255-268.

Mahadevan, S., J. D. Erfle, and F. D. Sauer. 1980. Degradation of soluble and insoluble proteins by Bacteroides amylophilus protease and by rumen microorganisms. J. Anim. Sci. 50:723-728.

McBeth, L. J., K. P. Coffey, W. K. Coblentz, D. H. Hellwig, J. E. Tumer, and D. A. Scarbrough. 2003. Impact of level of spontaneous heating during storage of bermudagrass hay on rumen in situ disappearance kinetics in steers. Anim. Feed Sci. Technol. 108:147-158

McDonald, P., A. R. Henderson, and S. J. E. Heron. 1991. The Biochemistry of Silage. Second ed. Cambrian Printers Ltd., Aberystwyth, UK.
Nakamura, T., T. J. Klopfenstein, and R. A. Britton. 1994. Evaluation of acid detergent insoluble nitrogen as an indicator of protein quality in nonforage proteins. J. Anim. Sci. 72:1043-1048.

NRC. 1993. Soil and Water Quality: An Agenda for Agriculture. National Academy Press, Washington, DC.

NRC. 2001. Nutrient Requirements for Dairy Cattle. National Academy Press Washington, DC.

Ogden, R. K., W. K. Coblentz, K. P. Coffey, J. E. Turner, D. A. Scarbrough, J. A. Jennings, and M. D. Richardson. 2006. Ruminal in situ disappearance kinetics of nitrogen and neutral detergent insoluble nitrogen from common crabgrass forages sampled on seven dates in northern Arkansas. J. Anim. Sci. 84:669-677.

Olmos Colmenero, J. J., and G. A. Broderick. 2006a. Effect of dietary crude protein concentration on milk production and nitrogen utilization in lactating dairy cows. J. Dairy Sci. 89:1704-1712.

Olmos Colmenero, J. J., and G. A. Broderick. 2006b. Effect of dietary crude protein concentration on ruminal nitrogen metabolism in lactating dairy cows. J. Dairy Sci. 89:1694-1703.

Peltekova, V. D., and G. A. Broderick. 1996. In vitro ruminal degradation and synthesis of protein on fractions extracted from alfalfa hay and silage. J. Dairy Sci. 79:612-619.

Pichard, G. 1977. Forage nutritive value. Continuous and batch in vitro rumen fermentations and nitrogen solubility. Cornell Univ., Ithaca, NY.

Pichard, G., C. Tapia, and R. Larrain. 2005. Ruminal proteolysis in forages with distinct endopeptidases activities. Page 273 in Proc. XIVth Int. Silage Conf., Belfast, UK.

Reid, R. L. 1994. Nitrogen components of forages and feedstuffs. Pages 43-70 in Principles of Protein Nutrition of Ruminants. J. M. Asplund, ed, CRC Press, Boca Raton, FL.

Reynal, S. M., and G. A. Broderick. 2003. Effects of feeding dairy cows protein supplements of varying ruminal degradability. J. Dairy Sci. 86:835-843.

Reynal, S. M., and G. A. Broderick. 2005. Effect of dietary level of rumen-degraded protein on production and nitrogen metabolism in lactating dairy cows. J. Dairy Sci. 88:4045-4064.

Reynal, S. M., G. A. Broderick, S. Ahvenjarvi, and P. Huhtanen. 2003. Effect of feeding protein supplements of differing degradability on omasal flow of microbial and undegraded protein. J. Dairy Sci 86:1292-1305.

Reynal, S. M., G. A. Broderick, and C. Bearzi. 2005. Comparison of four markers for quantifying microbial protein flow from the rumen of lactating dairy cows. J. Dairy Sci. 88:4065-4082.

Reynal, S. M., I. R. Ipharraguerre, M. Lineiro, A. F. Brito, G. A. Broderick, and J. H. Clark. 2007. Omasal flow of soluble proteins, peptides, and free amino acids in dairy cows fed diets supplemented with proteins of varying ruminal degradabilities. J. Dairy Sci. 90:1887-1903

Rossi, P., C. Boin, M. L. V. Bose, R. D. Wanderley, and A. G. da Silva. 1997. Ruminal degradability of the neutral fiber and neutral detergent insoluble nitrogen of the corn silage and soybean meal in the Nelore cattle. J. Bras. Soc. Anim. Sci. 26:608-615.

Schwab, C. G., P. Huhtanen, C. W. Hunt, and T. Hvelplund. 2005. Nitrogen requirements in cattle Pages $13-70$ in Nitrogen and Phosphorus Nutrition ofC. E. Pfeffer and A. Hristov, ed. CABI Publishing, Wallingford, UK.

Seo, S., L. O. Tedeschi, C. Lanzas, C. G. Schwab, and D. G. Fox. 2006 Development and evaluation of empirical equations to predict feed passage rate in cattle. Anim. Feed Sci. Technol. 128:67-83.

Sniffen, C. J., J. D. Oconnor, P. J. Van Soest, D. G. Fox, and J. B. Russell. 1992. A net carbohydrate and protein system for evaluating cattle diets. 2. Carbohydrate and protein availability. J. Anim. Sci. 70:3562-3577.

Tedeschi, L. O. 2006. Assessment of the adequacy of mathematical models. Agric. Syst. 89:225-247.

Theil, H. 1961. Economic forecasts and policy. Pages 6-48 in Contributions to economic analysis. R. Strotz, J. Tinbergen, P. Verdoorn, and H. J. Witteveen, ed. North-Holland Publishing Company, Amsterdam, the Netherlands. 
Van Kessel, J. S., and J. B. Russell. 1996. The effect of amino nitrogen on the energetics of ruminal bacteria and its impact on energy spilling. J. Dairy Sci. 79:1237-1243.

Van Soest, P. J., C. J. Sniffen, D. Mertens, D. G. Fox, P. H. Robinson, and U. Krishnamoorthy. 1981. A net protein system for cattle: The rumen submodel for nitrogen. Pages 265-279 in Protein Requirements for Cattle: Symposium. Oklahoma State University Division of Agriculture bulletin MP-109, Stillwater.
Volden, H., L. T. Mydland, and V. Olaisen. 2002. Apparent ruminal degradation and rumen escape of soluble nitrogen fractions in grass and grass silage administered intraruminally to lactating dairy cows. J. Anim. Sci. 80:2704-2716.

Waters, C. J., M. A. Kitcherside, and A. J. F. Webster. 1992. Problems associated with estimating the digestibility of undegraded dietary nitrogen from acid-detergent insoluble nitrogen. Anim. Feed Sci. Technol. 39:279-291. 